\title{
ALLELOPATHIC ACTIVITY OF SOME WILD MUSHROOM IN INDONESIA
}

\author{
Ivan Permana Putra
}

Address (es):

IPB University, Faculty of Mathematics and Natural Science,Department of Biology, Jl. Agatis Kampus IPB Darmaga, 16680, Bogor Indonesia, (0251) 8622833.

*Corresponding author: ivanpermanaputra@apps.ipb.ac.id

\section{ABSTRACT}

To date, allelopathic activity of mushroom has not been reported in Indonesia. The aim of this study was to examine the allelopathic activity of wild mushroom extract through bioassay germination on Vigna radiata L. seed. A total of 13 wild mushrooms namely : Amanita sp.1, Armillaria sp.1, Armillaria sp.2, Auricularia sp., Clitocybe sp., Crepidotus sp., Fomitopsis sp., Ganoderma sp., Lepiota sp.1, Microporus sp., Panaeolus sp., Polyporus sp., and Rigidoporus sp. used for the material extraction. The extraction of 13 wild mushrooms was done using pure water. Pure extract $(25 \%, 50 \%$, and $75 \%)$ was applied by using sprayer directly on the seed for 7 days. The parameters observed including percentage of seeds germinating, length of radicles, and length of plumules. The highest germination rates as well as length of plumules and radicles were obtained in the negative control using distilled water, whilst Imperata cylindrica extract which used as positive control showed opposite result. Mushroom extract showed variation in the parameter observation. Rigidoporus sp., Daedalea sp.1, and Microporus sp. 2 seem to have the best activity of allelopathic effects, while Auricularia sp. consistently induced the highest effect of seed development. Overall, in line with few previously reports, this results can broadening the information of utilization of allelochemical properties of wild mushroom.

Keywords: Allelopathy, germination, plumule, radicle, seed, mushroom

\section{INTRODUCTION}

Weeds are plants which inhabit in a location where their occuranceare undesirable due to their adverse effects on the ecosystem or agriculture (Norris, 1992; Kim, 1994; Gadermaier et al., 2014). The weed control is one of the paramount aspects to obtain high yields on farming sectors. The herbicides application, which believe as powerfull tools in agricultural activity, has gradually increased since decades which contaminates the environment with serious consequences to all life form. Moreover, many reports the concerning of weeds resistance which is a consequence in most cases of mutations or preexistence of genes that confer resistance to the population (Agostinetto et al., 2002; Oliveira et al., 2014). Researchers also pointed that herbicidal toxic effect on non-target soil creatures which involve in degrading and decomposing organic matter (Nuret al., 2013; Wolmarans and Swart, 2014). Therefore, the need for biological weed control such as development of bio-herbicides has risen over the decades.

In the term of fungal utilization approach, fungal pathogens in weed control is mostly used. Wood and Morris (2007) discovered that the Australian gallforming rust fungus Uromycladium tepperianum assists to reduce the infestationof Acacia saligna at over 50 localities in South Africa. Another prime examples of using fungi in biocontrol of weed are the prosperous use of the European rust fungus Phragmidium violaceum to control European blackberry (Rubus sp.) inChile, the use of Puccinia chondrillina to control Chondrilla juncea (rush skeleton weed) in Australia, which is considered as the most astonishing successes ever performed with biocontrol (Tansey and Kendrick, 1992). However, it is important to consider that the secondary infection of fungal pathogens which can lead to a successive distribution of disease in the field. As a result, it is necessary to develop another alternative weed control methods, which besides, again can reduce some negative environmental impacts.

Some organisms including plants and fungi release allelochemicals which can alter the organisms around them.Only few studies proved that macro fungi species have allelopathic potential (Araya, 2015; Kara, 2018; Osivand et al., 2018). Allelochemicals released by mushrooms may have specific effects on the growth and development of neighboring plants. Araya (2015) proposed that the allelochemicals releasing mechanism from mushrooms are similar to those in common plants. The allelopathic effects of mushrooms rely on hyphae biomass, the allelochemicals itself, and the tolerance of affected organisms (e.g., plants or insects) (Fujiiet al., 2004). Accordingly, using wild filamentous hyphae with fruiting bodies would be ideal for assessing the allelopathic potential of mushrooms (Osivand et al., 2018). Since it is difficult to collect large amounts of filamentous hyphae for bioassay, the most feasible option is to use fruiting bodies, which collectable in aggregates (Araya, 2015). As Indonesia poses high diversity of mushroom both in forest and natural park area (Putra et al., 2017; 2018; 2019), it is needed to explore allelophatic activity from many kind of wild mushrooms. Different mushroom species act as a promising source for the production of various compounds that can be used as potential herbicides. The objective of this study was to observe allelopathic activity of wild mushroom extract through bioassay germinationon Vigna radiata $\mathrm{L}$ seed. This research is the first report of allelopathic activity of mushroom extract in Indonesia.

\section{MATERIAL AND METHODS}

\section{Wild Mushroom Extract Preparation}

A total of 13 wild mushrooms namely :Amanita sp.1, Armillaria sp.1, Armillaria sp.2, Auricularia sp., Clitocybe sp., Crepidotus sp., Fomitopsis sp., Ganoderma sp., Lepiota sp.1, Microporus sp., Panaeolus sp., Polyporus sp., and Rigidoporus sp., were collected from Mekarsari Tourism Park, Indonesia in July 2017 and Gede Pangrango Mountain National Park, Indonesia in July-August 2018 as described by Putra et al. (2018; 2019). Epigeal parts of the mushrooms were cleaned, dried, and then grounded by blender into small pieces. Then $50 \mathrm{~g}$ was taken in to bottom flask and $500 \mathrm{ml}$ distilled water was added on it (1:10)(W/V) (Wardle $\boldsymbol{e t}$ al., 1992). Mixture was stirred for $10 \mathrm{~min}$ and then slurry was filtered through filter paper (whatman No:1) and centrifuged in $4000 \mathrm{rpm}$ for 10 minutes to obtain pure extracts. Obtained solution is diluted with distilled water to prepare different concentrations $(25 \%, 50 \%$, and $75 \%)$.

\section{Seed Preparation}

Seeds of Vigna radiata L. used in this study were obtained from the local market. They were soaked in distilled water for 12 hours. The water was drained and the seedling were ready for allelopahtic test (day 1 ).

\section{Allelopathic bioassay test}

The experiment was conducted according to Kara (2018) with three replications. The seedlings were kept moist by spraying (2 times a day) tap water, Imperata cylindrica extract, and the wild mushroom extract in a covered Petri dish with sterile cotton. Germinated seeds were recorded on day $7^{\text {th }}$ after sowing. The parameters observed including percentage of seeds germinating, length of radicles, and length of plumules. Imperata cylindrica extract served as the positive control group since they have the propertyof allelopathic effects (Eussen, 1979; Inderjit and Dakshini, 1991; Cerdeira et al., 2012), while distilled water was the negative control group. The results were obtained under laboratory conditions. 


\section{RESULTS AND DISCUSSION}

Allelopathic bioassay test using extracts derived from 13 wild mushroom showed that the aqueous extracts of wild mushroom posses allelochemicals that suppressed the germination and seedling growth of Vigna radiata L. (Table 1). A hundred percent of germination rate were obtained by extract of Amanita sp.1, Lepiota sp. 1, Crepidotus sp., and Clitocybe sp. Treatment as well as distilled water, while Rigidoporus sp. extract is the only treatment which the germination of Vigna radiata L. seeds never existed. Rigidoporus has been known as causative agent of white root disease which is the most destructive root disease in rubber plantation (Silva et al., 2017). It is still unclear which bioctive properties of Rigidoporus play key role of allelopathic effects. Falade $\boldsymbol{e t}$ al. (2017) reported that the bioactive compounds found in the extracts of Rigidoporus microporus (SW) were hexadecane, n-hexadecanoic acid, pentadecanoic acid, octadecane, hexadecanoic acid, n-octadecenoic acid, di-noctyl phthalate (1,2- benzenedicarboxylic acid, dioctyl ester) and n-decanoic acid. However, the use of Rigidoporus extract in weed management has never been done before. The seeds germination with Imperata cylindrica treatment only occured at $25 \%$ concentration, in contrast to Daedalea sp.1 which germination emerged only at $75 \%$ concentration. Members of the genus Daedalea are brown-rot fungi which have been used for biodegradation due to their capability of producing hydroxyl radicals in the Fenton reaction (Purnomo et al., 2008; 2010; 2011). Hydroxyl radicals are highly reactive species which attack most of the organic molecules (Lester, 2008). Based on the results of this study, Daedalea sp. can also be good candidate for further observation on its allelopathic effects. The rest of treatment showed successfull germination rate from $33.3 \%-100 \%$. This study proved that different mushroom extract varying in the seeds germination effect.

Table 1 Germination rates of Vigna Radiata L. seeds

\begin{tabular}{cccc} 
Groups & \multicolumn{3}{c}{ Germination rates (\%) } \\
\cline { 2 - 4 } Polyporus sp. & 25\% Extract & $50 \%$ Extract & $75 \%$ Extract \\
Armillaria sp. 1 & 66.7 & 100 & 66.7 \\
Armillaria sp. 2 & 66.7 & 66.7 & 0 \\
Microporus sp. & 66.7 & 100 & 66.7 \\
Fomitopsis sp. & 33.3 & 33.3 & 33.3 \\
Daedalea sp.1 & 0 & 66.7 & 33.3 \\
Rigidoporus sp. & 0 & 0 & 66.7 \\
Panaeolus sp. & 0 & 0 & 0 \\
Amanita sp. 1 & 100 & 66.7 & 100 \\
Lepiota sp. 1 & 100 & 100 & 100 \\
Auricularia sp. & 100 & 100 & 100 \\
Crepidotus sp. & 100 & 100 & 66.7 \\
Clitocybe sp. & 100 & 100 & 100 \\
Imperata & 66.7 & 100 & 100 \\
cylindrica & & 0 & 0 \\
Distilled water & & &
\end{tabular}

In the term of radicle development, the longest length possed by Auricularia sp. extract in all concentration compare to all treatment and negative control, whilst Rigidoporus sp. extract was the only treatment in all concentration which the radicle was not growth. The Rigidoporus sp. allelopathic effect was even better compare to Imperata cylindrica (positive control) and Daedela sp.1 (Fig 2). It is still uncertain which bioctive properties of Auricularia sp. act as inducer of seed germination in this study. Chang and Miles (1989) reported that nutritional content of Auricularia are $89.1 \%$ water, $4.2 \%$ protein, $5.3 \%$ fat, $2.8 \%$ carbohydrate, $19.8 \%$ fiber, and $351 \mathrm{mg}$ calories. The rest of treatment showed variation in the effect of radicle length. The shortest radicle length was $0.3 \mathrm{~mm}$ (Microporus sp. 2 treatment) while the longest was $5.7 \mathrm{~mm}$ (Auricularia sp. treatment). Osivand et al., (2018) proved that Microporus vernicipes extract has allelopathic effects on Lactuca sativa var. Great Lakes 366. However, there is no record yet on bioactive properties of this mushroom. This research findings showed that Microporus group also can be feasible candidate for weed management by mushroom allelopathic-based effects.

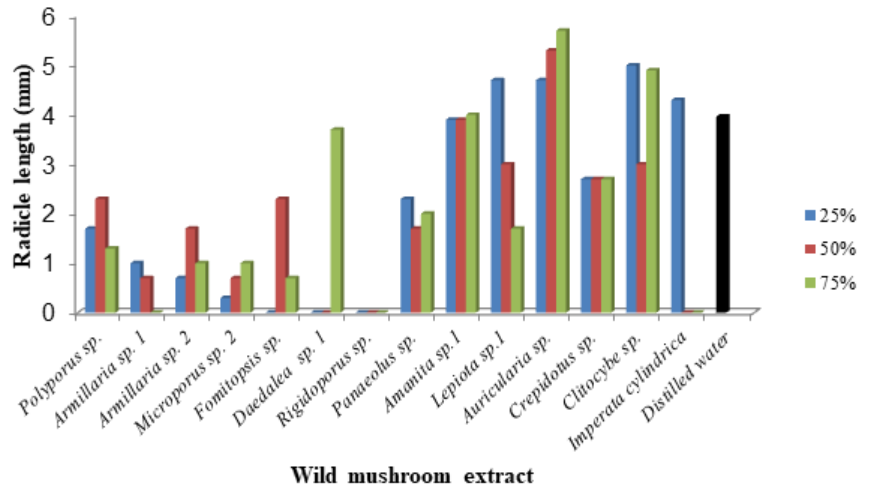

Figure 1 Effect of aqueous extract of wild mushroom on radicle length of Vigna radiata L. after 7 days. Extract concentrations (25\%, 50\%, and 75\%). (-) Control :distillled water, (+) control : Impererata cylindrica aqueous extract.

Turning to the plumule length, all of treatment showed allelopathic effect inhibition on plumule development while Auricularia sp. was the only mushroom extract which induce plumule growth (Fig 3). This is also interesting since positive control only inhibit the plumule growth at $25 \%$ concentration whilst negative control showed adequate inducing effect on Vigna radiata $\mathrm{L}$. plumule development. The longest plumule was $4.8 \mathrm{~mm}$ ( $25 \%$ of Auricularia sp. extract) while distilled water treatment only $4.7 \mathrm{~mm}$. The plumule part of the seed is emerge after growth of radicle, which comes out from the seed during germination. This study confirmed that all of wild mushroom extract used (except Auricularia sp.) inhibit the plumule development of Vigna radiata L. even though the radicle was emerged. Further study for evaluating the alllelopathic effect wild mushroom to the common weed as well as observation of its specific allelochemicals is necessary, in order to to develop alternative weed control methods, which can reduce some negative environmental impacts in Indonesia

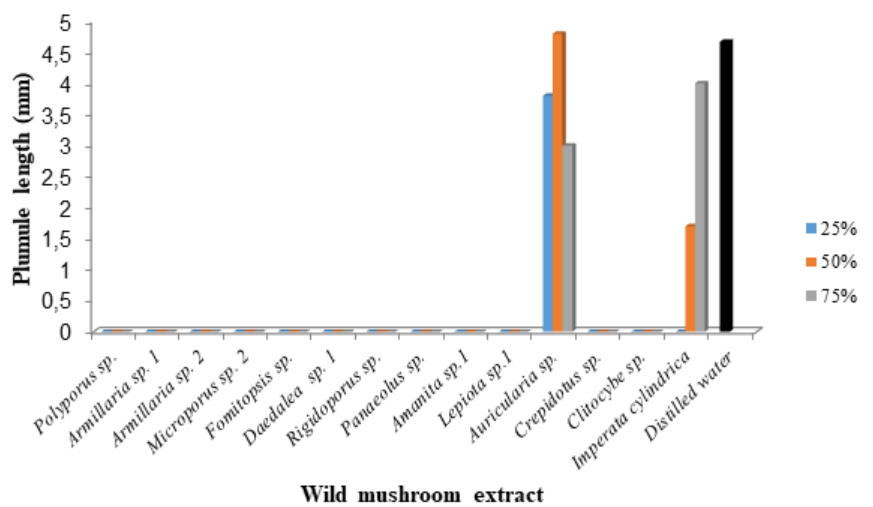

Figure 2 Effect of aqueous extract of wild mushroom on plumule length of Vigna radiata L. after 7 days. Extract concentrations (25\%, 50\%, and 75\%). (-) Control :distillled water, (+) control : Impererata cylindrica aqueous extract.

\section{CONCLUSION}

The present study provides the evidence of allelopathic activity of wild mushroom in Indonesia. It is also recommend that mushroom allelopathic effects should be consider used as prospective bio herbicides for weeds management. Extract of Rigidoporus sp., Daedalea sp.1, and Microporus sp. 2 are the most potential candidates for further obsevation.

\section{CONFLICT OF INTEREST}

The author declared that present study was performed in absence of any conflict of interest.

Acknowlodgement: Author thanks to Tiara Aulia Dinindaputri, M. Aldi Nasrulloh, Rahmadi Sitompul, and Nadiah Chalisya for their assisance. 


\section{REFERENCES}

AGOSTINETTO, D., VIDAL,R.A., FLECK, N.G., RIZZADI,M.A. 2002. Resistência de Plantas Aos Herbicidas Inibidores Da Enzima

Acetil Coenzima A Carboxilase (ACCase). Revista Brasileira de Herbicidas, 3, 155-161. http://dx.doi.org/10.7824/rbh.v3i2-3.388

ARAYA, H.,2015. Allelopathy of Mushrooms. In New Developments in Allelopathy Research; Price, J.E., Ed.;Nova Publisher: New York.

p. 1-14.ISBN: 978-1-63483-390-5

CERDEIRA, A.L., CANTRELl, DAYAN, F.E., BYRD, J.D., DUKE, S.O. 2012. Tabanone, a New Phytotoxic Constituent of Cogongrass

(Imperata Cylindrica). Weed Science, 60(2) : 212-

218.https://doi.org/10.1614/ws-d-11-00160.1

CHANG, S.T., MILES, P.G. 1989.Edible Mushrooms and Their Cultivation.

CRC Press, Inc., Florida, 345 p.ISBN : $084936758 X$

EUSSEN, J. H. H. (1979). Some competition experiments with alang-alang (Imperata cylindrica (L.) Beauv.) in replacement series. Oecologia, 40(3), 351356. http://dx.doi.org/10.1007/bf00345330

FALADE, O.E., OYETAYO, V.O., AWALA, S.I. 2017. Evaluation of the mycochemical composition and antimicrobial potency of wild

macrofungus, Rigidoporus microporus (Sw). The Journal of Phytopharmacology. 6, 115-125.

FUJII, Y., SHIBUYA, T., NAKATANI, K., ITANI, T. HIRADATE, S., PARVEZ, M.M. 2004. Assessment method for allelopathiceffect from leaf litter leachates. Weed Biol. Manag, 4,19-23. https://doi.org/10.1111/j.14456664.2003.00113.x

GADERMAIER, G., HAUSER, M., FERREIRA,F. 2014. Allergens of Weed Pollen: An Overview on Recombinant and Natural Molecules. Methods, 66(1): 55-66.https://doi.org/10.1016/j.ymeth.2013.06.014

INDERJIT, \& DAKSHINI, K. M. M. 1991. Investigations on some aspects of chemical ecology of cogongrass,Imperata cylindrica (L.) Beauv. Journal of Chemical Ecology, 17(2), 343-352.https://doi.org/10.1007/bf00994337

KARA, Y. 2018. Allelopathic Effects of Lyophyllum Platypum Mushroom Extracts on Seed Germination of Cynanchum Acutum Subspecies Acutum Weed. Bioscience Research, 15(2): 834-838.

KIM, S. 1994. Genetics of Maize Tolerance of Striga hermonthica. Crop Science, 34(4), 900-907. https://doi.org/10.2135/cropsci1994.0011183x003400040012x

LESTER, M. I. 2008. Quenching Dynamics of Electronically Excited Hydroxyl Radicals. https://doi.org/10.21236/ada482242

NORRIS, R. F.1992. Case History for Weed Competition/Population Ecology: Barnyardgrass (Echinochloa crus-galli) in Sugarbeets (Beta vulgaris). Weed Technology, 6(1), 220-227. https://doi.org/10.1017/s0890037x0003459x

NUR, M. M. Z., ROSLI, B. M., KAMARUZAMAN, S., MD, M. M., \& YAHYA, A. 2013. Effects of selected herbicides on soil microbial populations in oil palm plantation of Malaysia: A microcosm experiment. African Journal of Microbiology Research, 7(5), 367-374.https://doi.org/10.5897/ajmr12.1277

OLIVEIRA, C., AGOSTINETTO, D., VARGAS, L., ÁVILA, L. A., \& TAROUCO, C. P. 2014. Does the resistance to glyphosate herbicide affect the competitive ability of ryegrass with soybean? Planta Daninha, 32(1), 189-196. https://doi.org/10.1590/s0100-83582014000100021

OSIVAND, A., ARAYA, H., APPIAH, K., MARDANI, H., ISHIZAKI, T., \& FUJII, Y. 2018. Allelopathy of Wild Mushrooms-An Important Factor for Assessing Forest Ecosystems in Japan. Forests, 9(12), 773.https://doi.org/10.3390/f9120773

PURNOMO, A. S., KAMEI, I., \& KONDO, R. 2008. Degradation of 1,1,1trichloro-2,2-bis (4-chlorophenyl) ethane (DDT) by brown-rot fungi. Journal of Bioscience and Bioengineering, 105(6), 614621.https://doi.org/10.1263/jbb.105.614

PURNOMO, A. S., MORI, T., \& KONDO, R. 2010. Involvement of Fenton reaction in DDT degradation by brown-rot fungi. International Biodeterioration \& Biodegradation, 64(7), 560-565. https://doi.org/10.1016/j.ibiod.2010.06.008 PURNOMO, A. S., MORI, T., TAKAGI, K., \& KONDO, R. 2011.Bioremediation of DDT contaminated soil using brown-rot fungi. International Biodeterioration \& Biodegradation, 65(5), 691695.https://doi.org/10.1016/j.ibiod.2011.04.004

PUTRA, I.P., MARDIYAH, E., AMALIA, N.S., MOUNTARA, A. 2017. Ragam Jamur Asal Serasah Dan Tanah Di Taman Nasional Ujung Kulon Indonesia. Jurnal Sumberdaya Hayati, 3(1):1-7.

PUTRA, I. P., SITOMPUL, R., \& CHALISYA, N. (2018). Ragam Dan Potensi Jamur Makro Asal Taman Wisata Mekarsari Jawa Barat. Al-Kauniyah: Jurnal Biologi, 11(2), 133-150.https://doi.org/10.15408/kauniyah.v11i2.6729

PUTRA, I. P., NASRULLAH, M. A., \& DININDAPUTRI, T. A. 2019. Study on Diversity and Potency of Some Macro Mushroom at Gunung Gede Pangrango National Park. Buletin Plasma Nutfah, 25(2), 114.https://doi.org/10.21082/blpn.v25n2.2019.p1-14
SILVA, M. K. R., JAYASINGHE, C. K., \& TENNAKOON, B. I. 2017. Evaluation of the antagonistic effect of different plant species on white root disease causing fungus: Rigidoporus microporus. Journal of the Rubber Research Institute of Sri Lanka, 94(0), 25.https://doi.org/10.4038/jrrisl.v94i0.1822

TANSEY, M. R., \& KENDRICK, B. 1992. The Fifth Kingdom. Mycologia, 84(4), 610. https://doi.org/10.2307/3760341

WARDLE, D. A., NICHOLSON, K. S., \& AHMED, M. 1992. Comparison of osmotic and allelopathic effects of grass leaf extracts on grass seed germination and radicle elongation. Plant and Soil, 140(2), 315319.https://doi.org/10.1007/bf00010609

WOLMARANS, K., \& SWART, W. J. 2014. Influence of glyphosate, other herbicides and genetically modified herbicide-resistant crops on soil microbiota: a review. South African Journal of Plant and Soil, 31(4), 177-186. http://dx.doi.org/10.1080/02571862.2014.960485

WOOD, A. R., \& MORRIS, M. J. 2007. Impact of the gall-forming rust fungus Uromycladium tepperianum on the invasive tree Acacia saligna in South Africa: 15 years of monitoring. Biological Control, 41(1), 68-77. https://doi.org/10.1016/j.biocontrol.2006.12.018 